\title{
https://doi.org/10.34142/23129387.2019.60.13
}

УДК: 159.923

ORCID 0000-0002-5350-8305

ORCID 0000-0003-3528-7569

\section{РИТУАЛ ЗЦЛЕННЯ ЯК ТЕХНОЛОГІЯ ПСИХОЛОГІЧНОЇ РЕАБІЛІТАЦІЇ ОСІБ ІЗ ХІМІЧНИМ УЗАЛЕЖНЕННЯМ}

\author{
Олександр О. Фільц. ${ }^{\text {IABDE }}$, Кіра В. Седих ${ }^{2 A B C E}$ \\ ${ }^{1}$ доктор медичних наук, професор, завідувач кафедри психіатрії \\ ma nсuхотерапіi \\ Львівський національний медичний університет імені Данила \\ Галицького, \\ E-mail: pavenckyj.o@gmail.com \\ ${ }^{2}$ доктор психологічних наук, професор, завідувач кафедри \\ психології, \\ Полтавського національного педагогічного університету імені \\ В.Г. Короленка \\ E-mail: sedykhkira@gmail.com
}

Внесок авторів:

А - дизайн дослідження; В - збір даних; C - статистичний аналіз; D -підготовка статті; Е - збір коштів.

У статті розглянута програма реабілітації хімічно залежних «12 кроків» як ритуал зиілення. Описані різні аспекти ритуалу, фактори впливу та механізми виникнення як залежності, так $i$ тверезої поведінки хімічно залежних осіб.

Стаття містить опис особливостей фіксованої уяви як механізму виникнення узалежнення особистості. Визначена психологічна суть виливу імагінативного образу на поведінку особистості. Проаналізовані особливості фіксованої уяви у становленні залежності від адиктивного агента, ї̈ зв'язку з прочесом мислення, емоційною та мотиваційною сферою. Було визначено, що 
фіксована уява є иентром комунікації між іншими психічними проиесами: емоціями, пам'яттю, мотивацією та мисленням.

Також був описаний зв'язок фіксованої уяви із надиінними ідеями y прочесі формування адикиії. Визначена роль фіксованої уяви у процесі формування узалежнення дозволяє по-новому оцінити співвідношення різних сфер психічного в становленні адитивних механізмів, вперше акиентуючи увагу на иентральній ролі механізмів уяви у иььому процесі. Представлена роль фіксованої уяви на різних етапах формування адиктивного прочесу, специфіка фіксованої уяви як механізму виникнення узалежнення в підлітковому та ранньому юначькому віці. Була визначена модель узалежнення, яка задає нові рамки розуміння адиктивних механізмів та побудови практичної роботи з їх подолання з представниками підліткового віку.

Ключові слова: фіксована уява, система адикиії, узалежнення, надиінні ідеї, адиктивна мотивація, імагінативний образ, механізми виникнення узалежнення, лімінальність, потік, ритуал, ініціація.

\section{Healing ritual as a technology for the rehabilitation of individuals with chemical addiction Oleksandr O. Filtz', Kira V. Sedykh ${ }^{2}$ \\ 1 - Danylo Halytsky Lviv National Medical University 2 - Poltava V.G. Korolenko National Pedagogical University}

Aim of the study. The article deals with the "12 steps" program of chemically addicted persons rehabilitation as a ritual of healing. Different aspects of the ritual, factors of influence and mechanisms of addiction appearance and sober behavior of chemically addicted persons are described.

Results. The article contains a description of the peculiarities of a fixed imagination as a mechanism of the emergence of a person's addiction. The psychological essence of the imaginative image influence on person's behavior is determined. The peculiarities of the fixed imagination in the development of addiction from the addictive agent, its connection with the thinking process, emotional and motivational spheres are analyzed. It was determined that the fixed imagination is the centre of communication among other mental processes: emotions, memory, motivation and thinking.

The connection of fixed imagination with overvaluable ideas in the process of addiction was also described. The definite role of the fixed imagination in the process of addiction formation allows a new assessment 
of the ratio of various mental spheres in the development of addictive mechanisms, focusing on the central role of the mechanisms of imagination in this process for the first time. The role of the fixed imagination at various stages of the addictive process formation, the specifics of the fixed imagination as a mechanism of addiction appearance in teenage and early adolescence are presented.

Conclusions. The model of addiction was defined. It sets a new framework for addictive mechanisms understanding and construction of practical work with teenagers to overcome them.

Keywords: fixed imagination, addiction system, addiction, overvaluable ideas, addictive motivation, imaginative image, mechanisms of addiction appearance, liminality, flow, ritual, initiation.

Вступ. В останні роки у зв'язку із загостренням суспільної ситуації та підвищенням соціальної напруги питання, пов'язані iз здоров'ям та благополуччям особистості набувають особливої актуальності. У цьому контексті особливо гостро постає проблема адикції та технологій реабілітації хімічно залежних. Вектор спрямування на технології та умови реабілітації особистості на противагу до вектора, спрямованого на хворобу як таку, з необхідністю передбачає певне переосмислення вже відомих в психології феноменів. Це, в свою чергу, ставить питання щодо формування позитивних когнітивноповедінкових схем - диспозицій в структурі особистості. Наша спроба стосуватиметься формулювання концептуального підгрунтя для Програми, яка довела свою успішність на практиці протягом багатьох років. Завдяки поглибленю розуміння психо-соціо-біологічих впливів ми пропонуємо внести деякі корективи у вказану програму задля покращення результатів реабілітації.

Об'єктом дослідження виступає механізм зцілення як формування позитивних когнітивно-поведінкових схем диспозицій в структурі особистості.

Предметом вивчення є ритуал зцілення та роль фіксованої уяви у процесі реабілітації хімічно залежних осіб за реабілітаційною програмою «12 кроків».

Результати. Для розвитку реабілітаційного процесу важливо означити наше розуміння процесу формування 
узалежнення. Так, потреба у залежності/автономії $\epsilon$ універсальною властивістю людини. Однак, за певних умов, деякі нейтральні об'єкти, які відіграють важливу роль у формуванні залежної чи автономної поведінки перетворюються на надцінні для особистості, а потреба в них посилюється до неконтрольованого стану.

Нами (2018) сформульовано гіпотезу, що важливу роль у формуванні адиктивної поведінки може відігравати специфічний психологічний феномен, означений нами як фіксована уява. $\quad$ в уяві гіпертрофується певна частина дійсності $i$ добудовується у фантазї, завдяки чому створюеться емочійно насичена картинка (образ). Цей образ ми назвали фіксованою уявою (Фільц, Седих, 2018). Зупинимося детальніше на аналізі феномену «фіксована уява».

Відомо, що предмет (ситуація), із приводу якого виникають образи уяви, виступає як факт свідомості i, будучи завжди однозначно співвіднесеним із реальністю, $€$ iï чітко ідентифікованим фрагментом. Але, при цьому, такий фрагмент виступає тільки приводом для виникнення образів уяви і місцем ïх «стягування» у свідомості. Це означає, що конкретна реальність, будучи значимою для функиіонування уяви, не задає зміст образів-картинок. Уява спирається на відображувану миттєву реальність тільки як на привід для розгортання своїх власних картин, тоді як реальність є лише вихідним матеріалом. Якщо в площині відображення у свідомості фіксуються наявні і іманентно-імовірнісні стани предмету, то в площині уяви предмет постає у фіксованих, але необмежених у своӥх можливих проявах, станах (Голосовкер, 1987). Останнім часом наукові дослідження (Сапольски, 2017) доводять, що «Образи у свідомості і є уява», і ці образи існують у вигляді картин або образів моторного типу.

Відомо, що до системи адикції входять такі окремі елементи як мотивація, уява, емоції, пам'ять, мислення, тілесність і поведінка. При цьому, на нашу думку, особливістю та специфічністю цієї системи виступає фіксованість уяви,

Фіксована уява - емоційно насичений образ, що створюється на основі процесу гіпертрофування частини 
дійсності в уяві і іiі добудування у фантазії. Взаємодія емоції і образу розвивається по спіралі і поступово зумовлює фіксацію уявного образу. Створюється специфічна «амальгама» - сплав емоції і образу, який набирає самостійного надцінного значення (Фільц, Седих, 2018).

Коли система адикції вже сформована, то тригером для іiі активізації слугує об’єкт залежності (хімічний агент). Розмірковуючи над комунікацією процесів уяви та емоцій, треба зазначити наявність циркулярного зв'язку міжс ними. Так образи уяви завжди мають емоційне забарвлення, натомість, всяке почуття, всяка емоція прагне оформитись у певні образи, що відповідають цьому почуттю. Навіть коли вони не стосуються безпосередньо чи особисто до життєвої ситуації особи, то і тоді вони виразно переживаються нею як позитивні або негативні. Існують суттєві вікові відмінності у взаємодії між уявою та емочіями. Особа людини формується через мрії, «мами навчають дітей тому, про що «варто мріяти» (Knutson, 2000). Механізм утворення образу уяви у дитини відбувається по колу: образ породжує емоцію, а емоція - образ, який знову породжує і підсилює ту ж емоцію (Knutson, 2000).

На відміну від утворення образу уяви у дитини, утворення образу фіксованої уяви відбувається по спіралі через послідовне та поступове уточнення обидвох ії складових - образу уяви та приналежної емочії (Фільц, Седих, 2018).

Так, на першому етапі фіксована уява відображає емоційно насичений зв'язок між вживанням адиктивного агенту та появою реакції на вживання; Взаємодія емоції i образу розвивається по спіралі і поступово зумовлює фіксацію уявного образу. Так, емоція уточнює і уточнює образ; а сама емоція уточнюється також, і стає фіксованою на уточненому образі.

На наступному етапі 3'являються вторинні переживання, що виникають із приводу цих образів уяви, і самі ці образи отримують додаткову емоційну «зарядженість». Створюється специфічна «амальгама» - сплав емоції і образу, який набирає самостійного надцінного значення. При цьому розвивається надцінне емоційне ставлення i, врешті решт, формується надцінна ідея щодо об'єкта адикції. Провідна емоція - 
задоволення підбирає окремі елементи дійсності й комбінує їх у такий зв'язок, який обумовлений зсередини вже цим настроєм, а не ззовні, логікою самих ичих образів. Така комбінаторика притаманна сновидінням і мріям. Фантазія, керована таким емоиійним фактором - найбільш суб'єктивний, найбільш внутрішній вид уяви.

Поступово формується фіксований конструкт, де задіяні різні когнітивні процеси, і цей конструкт завдяки фіксованості та надцінності (Морозов, 1934) починає виконувати РЕГУЛЯТИВНУ функцію, яка регулює емоційні стани та керує сприйманням, спогадами й ін.; а також формус внутрішній план дій; планування і програмування життя. Тут, під регулятивною функцією ми розуміємо специфічне «накладання зобов'язань», яке $\epsilon$ неухильним наслідком інтерналізації (визнання та засвоєння) будь якої ідеї.

Відомо, що виникнення узалежнення частіше виникає в підлітковому та ранньому юнацькому віці (Короленко, Донских, 1990; Кулаков, 1998; Седих, Моргун, 2015; Уайнхолд, 2009; Пинкер, 2009). Виникає питання, чому саме підлітковий та юнацький вік $\epsilon$ найбільш сенситивними для виникнення аддикцій? Крім вже добре відомих факторів: загострена пристрасть до спілкування 3 ефектом угруповання; тяга до опору, конфронтації, протесту проти виховних авторитетів; амбівалентність і парадоксальність характерологічних реакцій; прагнення до незалежності та відриву від сім'ї (Седих, 2015; Сапольски, 2017); сучасні дослідження 3 психології та нейробіології розширяють наші уявлення про механізми утворення залежності.

Зосередимо нашу увагу на наступних факторах:

1. Задоволення - система нагороди.

2. Пошук новизни,прагнення до невідомого, ризику.

3. загострений інтерес до незвіданого, глобальних проблем і «універсальних» переживань;

4. криза ідентичності;

Так, переконливо доведено, що при важкому дитинстві у людини ушкоджується дофамінова система (система біологічної нагороди) і відповідно змінюються очікування та 
цілеспрямована поведінка особи (дофамін - стимулює діяльність і підтримує цілеспрямовану діяльність). Схематично, при формуванні хімічної залежності у схильних до цього осіб у дорослому віці - за рахунок підвищеного рівня глюкортикоїдів (що свідчить про хронічну схильність до тривоги), поступово виснажується «запас дофаміну», що знижує поріг збудливості. Відтак, такими особами стресова ситуація сприймається загострено (Steinberg, 2014; Goswick, 1982).

Пошук новизни (novelty seeking), тісно пов'язаний iз прагненням до невідомого та ризику, виявляється притаманним не тільки для підлітків-людей, але і для підлітків - приматів. Це пов'язано із тим, що протягом підліткового віку в мезолімбічному шляху і в мезокортикальній зоні - щільність та ефективність дофамінових аксонів неухильно збільшується і має характер надлишковості (потім, уже в дорослому віці, на основі природнього механізму прунінгу, кількість нейронів зменшується і досягає оптимуму для вирішення особою повсякденних завдань адаптації) (Greene, 2014; Knutson, 2000). Ці феномени пояснюються еволюційними психологами як різні поведінкові стратегії важливі для природного відбору. Вони налаштовані на зміни (у підлітків) та підтримання стабільності (у дорослих), що підвищує шанси популяції як до виживання, так і до розповсюдження власних генів для всієї спільноти. Зокрема, у тинейджерів та юнаків, завдяки появі загостреного інтересу до незвіданого, глобальних проблем і «універсальних» переживань, з неухильністю формуються необхідні узалежнення (закоханість, спорт, мистецтво, тощо).

Найменша дофамінова відповідь (у схильних до ризику підлітків це пов'язано із геном ризику) (Steinberg, 2014; Goswick, 1982), тобто найменше дофаміну, продукується у осіб 3 найбільш активно-ризикованою поведінкою. У тинейджерів ще незріла лобна кора, яка ще не має достатнього «інструментарію» для збалансованого функціонування дофамінової системи, підвищує ймовірність імпульсивної поведінки тинейджерів особливо у присутності однолітків.

Під час перших разів вживання наркотику спостерігається дуже великий викид дофаміну (що в рази перевершує «звичайну 
дозу») i, таким чином, особа отримує незвичні когнітивнотілесні переживання, які формують задоволення, в тому числі на рівні специфічного тілесного компоненту (отілеснення), важливого для формування майбутньої залежності. Пізніше, при подальших вживаннях наркотику спостерігається суттєвий спад дофамінового викиду, i, відповідно суттєве зменшення тілесного задоволення. Саме тут, як ми вважаємо, і включається механізм ФУ (фіксованої уяви), яка налаштовує людину на очікування задоволення та гонитву за ним. Це могло б пояснюватись тим, що дофамін виділяється очікуванні і психічної, і тілесної винагороди (reward dependency), що в результаті ще більше підкріплює отілеснений аспект узалежнення. Таким чином розвивається ще один процес циркулярності у взаємодії ФУ та Отілеснення.

Говорячи про формування адиктивної поведінки в підлітковому віці, ми особливо виділяємо мотив спілкування зі значущими особами (референтною групою) та мотив отримання власної ідентичності. Для підлітка питання «Що ти думаєш про себе» еквівалентно «Що про тебе думають інші», тобто дуже висока залежність від думки інших, референтною групою $є$ ровесники. В цьому віці характерна схильність до підвищеної емпатії, існує загостренне відчуття чужого болю, при цьому відчуття відрази зменшене, спостерігається надлишок емоцій (так звані лімбічні «віхори») та недорозвиненість кори головного мозку (Сапольски, 2017). Такі особливості як відкритість новому, егоїзм, відчуття власної всемогутності, недооцінка ризику відносно себе «зі мною цього не може статися», підвищують ризик розвитку хімічної залежності.

Набуття власної ідентичності відбувається через кризу переходу 3 підлітково-юнацького віку до дорослого. Для цього переходу необхідний певний ритуал - ініціація. Як було встановлено антропологом Ван Геннепом в так званих традиційних культурах важливу роль відігравали ритуали переходу - обряди, що виконувалися при зміні місця, стану, соціального положення, статусу. В цих ритуалах виділяють 3 фази: 1) сепарація; 2) граничний стан (поріг); 3) відновлення (цит. За В.Тернером, 1983). 
В сучасному цивілізаційному світі ця функція суспільства (спільноти) - створювати емоційно насичені ритуали переходу практично втрачена. Для переходу в інший статус у племінних спільнотах особистість піддавалася спеціально спланованим випробуванням і стражданням. В нашому суспільстві батьки не можуть самі створити таку ситуацію і не можуть виступати ініціюючими фігурами: для цього необхідними $є$ сторонні фігури зрілого чи старшого віку - посередники (наприклад, жрець, учитель, гуру або психотерапевт). В пошуках нової ідентичності підліток шукає символічні фігури переходу, i ритуали в субкультурі залежності виконують цю символічну функцію переходу - це і є своєрідна ініціація для підлітка.

Повертаючись до відчуття задоволення, слід ще раз сказати, щуо у підлітка це відчуття виникає у контексті приєднання до групи, спілкування $i$ отримання незвичних когнітивно-тілесних переживань. Завдяки реалізації мотивів спілкування зі значущими ровесниками та отримання власної ідентичності через відчуття приналежності до цієї групи створюється кататимно-імажинітивний образ нового (відмінного від батьків та сім’ї) «бажаного об'єкта». Кожна зокрема або декілька разом, названі нами фактори формують наступний етап системи адикції, а саме, адиктивну поведінку - визначається послідовність звертання до засобів адикції. Встановлюється визначена частота реалізації адиктивної поведінки, а відтак створюється специфічна ритуалізація поведінки.

Зрештою, вся субкультура залежності поступово стає кататимним переживанням: формується надцінне ставлення як до агента, так і до всієї субкультури.

Об'єкт залежності (хімічний агент, як адаптоген надшвидкої дії) стає перехідним об'єктом спілкування, символом стосунку і всієї субкультури, де ритуали окреслюють iii границі. На цьому етапі формування залежності, об'єкт залежності починає виступати центральним елементом системи спілкування і як «членський квиток» цієї спільноти, i як «посвідчення» особи, і врешті-решт, позначає собою вагому частину ідентичності. (ясно, що не всю ідентичність - тому треба обережніше). Через ритуали та розмови про хімічний 
агент створюється і підтримується наркоманічна (алкогольна) адиктивна субкультура: адиктивний агент виступає в якості тригера, який запускає процес кататимного узалежнення від об'єкту - хімічної речовини.

Таким чином, нами описана циркулярна модель формування системи узалежнення: ФІКСОВАНА УЯВА АПРОБАЦІЯ В РЕАЛЬНИХ ДІЯХ - ОТІЛЕСНЕННЯ ЗАДОВОЛЕННЯ - ПОВЕДІНКОВИЙ РИТУАЛ, ЯК ФІКСОВАНА ПОВЕДІНКА ДЛЯ РЕАЛІЗАЦІЇ ЗАДОВОЛЕННЯ ПОТРЕБ ФІКСОВАНОЇ УЯВИ - НАДЦІННА ІДЕЯ ЯК ПЛАНУВАННЯ ПОВЕДІНКИ

Визначена модель задає нові рамки розуміння адиктивних механізмів та побудови практичної роботи з їх подолання.

Процес реабілітації. На цьому етапі дослідження нашим завданням було вивчити психологічний механізм реабілітації хімічно узалежнених клієнтів в процесі проходження ними Програми 12 кроків. Програма 12 кроків існує 83 роки, була започаткована у США двома алкоголіками у 1935 році і отримала підтримку Карла Юнга (Анонімні алкоголіки...). Ця програма реабілітації вважається найбільш ефективною для хімічно узалежнених осіб (для алкоголіків вона отримала назву АА, для наркоманів - АН). Але, незважаючи на іiі дієвість i довготривалість, програма досі не отримала належної уваги та аналізу психологічних механізмів зцілення в площині академічної психології. Ми вважаємо, що створення програми стало можливим завдяки «універсальній інстинктивній психології» (спираючись на ідеї еволюційної психології ми вводимо це поняття і в подальших роботах збираємось його розвинути). На нашу думку, саме цей уроджений інстинкт, притаманий Homo sapiens як біологічному виду, запускає здібності соціальної та емоційної інтуїції у людини. Саме це пояснює можливість швидкого научіння новим психологічним навичкам у людей і роботу волонтерів, які не мають спеціальної академічної психологічної та психотерапевтичної підготовки, але здатні засвоїти та передати іншим певні психологічні знання.

На нашу думку, психологічними цілями реабілітації $є$ 
отримання нового соціально-психологічного статусу і нової ідентичності через психотерапевтичну програму. Спираючись на ідеї В. Тернера щодо культурних ритуалів зцілювання (Тэрнер, 1983) ми визначили, що психотерапевтична програма 12 кроків, яка триває 28 днів в Центрах реабілітації хімічно залежних, фактично сама і $є$ повноцінним Ритуалом Зцілення. Раніше в цій статті ми вже акцентували увагу на значущості здійснення ритуалів Переходу при зміні соціального або психологічного статусу особи. Як зазначає М. Чиксентмихайї, будь-які ритуали переслідують мету - за допомогою здійснення схематизованих дій відновити порядок у свідомості особистості (Чиксентмихайи, 2018). Сам ритуал ми розглядаємо - в так званому «польовому контексті» (термін В. Тернера (1983)), в конкретно-історичних умовах, а саме, в процесі реабілітації. Друга фаза культурного ритуалу має назву лимінальної, тобто проміжної, порогової, в якій 3 великою емоційністю затверджуються нетлінні цінності суспільства, до нового закріплення структури (іноді видозміненої) (Тэрнер, 1983). В цій фазі особа отримує подвійні риси і статус лімінальності. Лімінальні персони мають амбівалентність, оскільки втратили попередній статус і місце в суспільстві. неофіт в лимінальності повинен бути tabula rasa, чистою дошкою, на якій записують знання і мудрість групи, що стосуються нового статусу. Клієнти шукають трансформативного досвіду, який проникає до самого коріння буття кожної людини і знаходить в цих коренях щось глибинно загальне i всіма поділюване. Вірогідно, що психологічний сенс лимінальності у психотерапевтичних клієнтів - це ознака готовності особи для набуття нового статусу i нової ідентичності, при втраті попередньої ідентичності і попередніх смислів.

Наведемо ознаки лимінальності: перехід, рівність, гомогенність, комунітас, анонімність, відсутність власності, відсутність статусу, оголеність (або однаковий одяг), статеве утримання, зведення статевих відмінностей до мінімуму; відсутність звань, смиренність, байдужість до зовнішнього вигляду, немає відмінностей матеріальних, безкорисливість, підлеглість всім, сакральність, сакральні настанови, мовчання. 
Фільц О., Седих К. Ритуал зцілення як технологія ...

В життєвому досвіді кожної людини має місце чергування структури і комунітас, станів і переходів.

Ознаки структури в соціумі: соціальний статус, нерівність, гетерогенність, структура, система номенклатури, власність, відмінність в одязі, статеве життя, максималізація статевих відмінностей, різниця звань, гордість своїм положенням, турбота про зовнішній вигляд, матеріальні відмінності, себелюбство, підлеглість тільки вищестоячим, секулярність, технічні знання, мовлення.

Під час Ритуалів ініціації в традиційних суспільствах спеціально створювалися умови, під час яких неофіти переживали фізичні та моральні страждання. Виникає питання: для чого? Сучасні нейробіологічні дослідження відкрили, що функція страждання - руйнування існуючої нейрональної структури (Сапольски, 2017). На психічному рівні це означає розрив попередніх кліше і шаблонів як в сфері когніцій, так і в сфері поведінки. Отже, страждання створюють підгрунтя для інтенсивного Научіння (на нейробіологічному рівні утворюються нові аксони, нові нейрональні зв'язки і шляхи (Сапольски, 2017), а також отілеснюють переживання.

1) Першим кроком для участі в Програмі 12 кроків є абстиненція, яка призводить до страждань. На 1- кроці в групі АА, НА у клієнтів виникає соціально-психологічний статус лимінальності (порогові люди), приймання позиції «Я безсилий» (перед хімічним агентом) означає втрату попереднього статусу - наркомана (алкоголіка)і $є$ сигналом внутрішньої готовності до нового статусу - «Я- твереза Людина».

2) Образ «Я» наркомана у вживанні: «я - нормальній, але унікальний в складних обставинах», цей самонаратив $\epsilon$ частиною наркоманічного загального міфу - Міфу унікальності, «Я - крутий». Наступний образ «я»: я - хворий (коли починається лікування). Відбувається покрокова зміна образу «Я-залежний» 3 позитивного ставлення і оцінки на негативні.

Символи ритуалу мають синтезуючий характер, що об’єднує у собі різнорідні та логічно несумісні ідеї. Існують три способи символічної референції: 1) явний сенс, що 
Фільц О., Седих К. Ритуал зцілення як технологія ...

відноситься експліцитно цілям ритуалу і повністю усвідомлюваний виконавцями; 2) латентний зміст, що знаходиться на межі свідомості суб'єкта, але здатний бути повністю усвідомленим; 3) прихований сенс, повністю несвідомий і відноситься до базового (інфантильного) досвіду, спільного для всіх людських істот (Тэрнер, 1983).

В реабілітаційній програмі явним сенсом виступає мета стати тверезим. Латентним сенсом є розвиток духовності, прихованим сенсом є відновлення (або поява) почуття довіри до світу і себе через прийняття і жорстку любов.

Завдяки Р3 актуалізуються Механізми нейропсихологічних змін методами:

1. Научіння новим когнітивно-поведінковим схемам.

2. Повторюваність. Повторення знайомих ритуалів активує частини кори ГМ, що пов'язані зі звичками та несвідомими оцінками. Повтор заучених молитов - активує мезолімбічну діяльність.

3. Опанування сильними емоціями: ненависті, страху, любові, горя; формується більша здатність керувати власними афектами.

4. Створення нових ресурсних кататимно-імагінітивних образів ФУ та перехід на інший рівень моральних настанов.

Як ми вже зазначали вище, кора головного мозку у людини формується до 25 -30 років. Хімічний агент блокує як розвиток КГМ, так і функціонування тих відділів кори, які відповідають за логічну регуляцію поведінки. В період реабілітації відсутність хімічного агенту надає можливість відновити розвиток певних коркових частин, відбувається інтенсивна розбудова нових зв'язків в КГМ (научіння через страждання) це дозволяє актуалізувати процеси усвідомлення, рефлексії своєї поведінки та формування пропущеного в онтогенезі цих пацієнтів етапу моральних суджень. В процесі нормального розвитку особистості у дорослих моральні судження стають більш «витонченими» та складними. Цього не відбулося у осіб із хімічними залежностями, які стали узалежненими в підлітковому та юнацькому віці. Перехід на новий рівень моралі відбувається під час реабілітації. Дослідження етологів 
висвітлили існування зачатків моральних суджень вже у приматів і довели контекстуальну залежність моралі від внутрішньогрупової просоціальності, - Грін «наш моральний мозок постійно розвилася аби сприяти розповсюдженню генів» (Палмер, Палмер, 2006; Green, 2014). Це пояснює інстинктивно психологічну детермінацію в інтеріоризації індивідом цінностей референтної для нього групи. В нашому контексті, хімічно залежні привласнюють цінності наркоманічної (алкогольної) субкультури, а на етапі реабілітації засвоюють групові норми моралі тверезої поведінки, які обговорюються на заняттях програми 12 кроків.

Під час ритуалу переходу до нової ідентичності у хімічно залежної особи необхідно створити нові кататимноімажінитивні образи Фіксованої уяві. Вони починають конкурувати з попередніми образами ФУ, наприклад паралельно 3 бажаним об'єктом - «образ-страшилка» або створюється кататимно-імажинативний образ «себе бажаного» або «образвідраза». (В психології мало досліджена така емоція як відраза. 3 фізіологічного боку відраза активує діяльність структури головного мозку «островок» (Сапольски, 2017). При цьому виникає відчуття нудоти від образів (уявлень) або думок про погані вчинки, коли залежний починає усвідомлювати і уявляти себе i малює свій образ неприємним, відразливим. В підлітковому віці знижено почуття відрази (Сапольски, 2017), це також сприяє втягуванню тінейджерів в наркома нічну субкультуру (антисанітарія умов не відштовхує). В період реабілітації відчуття відрази у клієнтів збільшується.

Вплив уяви на виникнення нових компетентностей людини було доведено в цікавих експериментах, де людей навчали грати на піаніно. Так, як показали ці дослідження, якщо людина уявляє протягом 2 годин на день, що грає на піаніно, в КГМ розростаються дендрити, як і під час реальних вправах на цьому музичному інструменті (Сапольски, 2017, с.804) . Ці результати стають іще одним доказовим підгрунтям для нашої гіпотези впливу уяви на розвиток різних форм поведінки: i узалежнення, i тверезості. Через вправи 3 візуалізації як цілеспрямованого процесу, який вимагає свідомих зусиль 
Фільц О., Седих К. Ритуал зцілення як технологія ...

формується фіксована уява, яка функціонує вже автоматично, без втручання свідомості.

Доказом циркулярних зв'язків між ФУ та отілесненням може слугувати гіпотеза соматичних маркерів Домасіо: «коли особа приймає рішення, то вона уявляє не тільки образи майбутнього «Експерименту», але і їх чуттєве супроводження: «якщо це відбудеться як я буду себе почувати?». Людина відчуває як ці почуття будуть відчуватися (це механізм так званого стратегічного консеквенціалізму 3 далекою перспективою, при цьому включаються різні відділи головного мозку: міндаліна, островок, вмПФК, длПФК , і вони діють як ансамбль) (Goswick, 1982; Greene, 2014).

Таким чином, створюється певний малюнок переживання, який корелює 3 певною конфігурацією задіяних нейронів і через Отілеснення або ФУ відбувається активація частин кори, які пов'язані 3 певним досвідом. Підкріплення цієї поведінки відбувається завдяки такому нейротрансміттеру як серотонін та гормону оксітоцин.

Довіра до Своїх, недовіра до Чужих - $\epsilon$ одним 3 універсальних біологічних законів просоціальної групової поведінки, що характерно не тільки для людей, але й для приматів (Сапольски, 2017). Довіра є базовим фактором для сприймання норм субкультури тверезості. Тому особливо важливу роль відіграють колишні залежні в програмі реабілітації. «Тверезий алкоголік, який встав на шлях одужання та озброєний знаннями про себе, може, як правило, завоювати повну довіру іншого алкоголіка за якісь години. I поки таке взаєморозуміння не досягнуто, небагато чого можна домогтися» (Анонімні алкоголіки...). Довірливе, емпатичне спілкування породжує прив'язаність (завдяки викиду окситоцину виникає отілеснення цього емоційного переживання), формується почуття спільноти, тобто «Чужі» стають «Своїми».

В процесі проходження програми 12 кроків у залежних пацієнтів розвиваються нові стани свідомості, в тому числі стан Потоку - 12 крок («Отримавши духовне пробудження в результаті виконання цих кроків, ми намагалися донести цю звістку до інших алкоголіків і здійснювати ці принципи у всіх 
своїх справах») (Анонімні алкоголіки...). 12 крок виконується учасниками програми 3 великим ентузіазмом, безоплатно на волонтерських засадах, 3 духовним піднесенням. Перехід від залежності до потоку є позитивним для цих осіб. Між станом залежності і станом потоку (поняття введено Чиксентміхайї (2018)) є важливі спільні риси, але при цьому є і принципові відмінності.

Як зазначає Чиксентміхайї, Поток - це коли людина вкладає всю свою психічну енергію у взаємодію, будь то 3 іншою людиною, 3 човном, горою або музикою. I тоді суб'єкт стає частиною системи, більшою, ніж та, що раніше представляла собою його індивідуальна особистість. Ця система функціонує за правилами тієї діяльності, в якій вона виникає, i наповнюється енергією уваги суб'єкта, який цю діяльність здійснює. При цьому вона не менш реальна, ніж сім'я, корпорація або команда. Особистість, яка стала ії частиною, розширює свої кордони і стає більш складною, ніж раніше (Чиксентмихайи, 2018).

Програма 12 кроків створює для клієнта можливість відчути себе частиною більшої системи («Товариство Анонімних Алкоголіків»). І тим самим досягнути стану Потоку

Висновки. Отже ми знаходимо в Програмі 12 кроків необхідні ознаки ритуалу ініціації: Процес реабілітації проводить особу шляхом «від хаосу лимінальності до порядку нової структури особистості».

У формуванні нової Тверезої ідентичності у залежних важливу роль відіграє феномен фіксованої уяви через механізм утворення кататимно-імагінативного образу «тверезої успішності». Фіксована уява при цьому виступає центром комунікації між іншими психічними процесами: емоціями, пам'яттю, мотивацією та мисленням; утворюється новий сталий конструкт «Я - тверезий», який бере на себе регулятивну функцію поведінки, замість конструкту «Я - залежний».

\section{Література}

Анонімні алкоголіки, Alcoholics Anonymous World Services, Inc., New York. - 1994. - 141 c. 
Голосовкер Я. Э. (1987). Логика мифа. М. 1987. С. 114-165.

Короленко Ц.П., Донских Т.А. (1990). Семь путей к катастрофе. Деструктивные формы поведения в современном мире. Новосибирск : Наука, 192 с.

Кулаков С.А. (1998). Диагностика и психотерапия аддиктивного поведения у подростков. М.: Фолиум, 70 с.

Морозов В.М. (1934). К вопросу о сверхценных идеях. Труды института им. П. Б. Ганнушкина. М. С. 338-349.

Палмер Дж., Палмер Л. (2006). Секреты поведения Homo Sapiens. Эволюционная психология. М. Прайм-тайм: Еврознак, 496 с.

Пинкер С. (2009). Язык как инстинкт. Издание 2-е, исправленное. Издательская группа «URSS», 456 с.

Сапольски Р. (2017). Биология добра и зла. Как наука объясняет наши поступки. М.: Изд-во Альпина нон фикшен, 485 с.

Седих К.В., Моргун В.Ф. (2015). Делінквентний підліток. Навч. посібн. К. : Видавн. дім «Слово», 272 с.

Тэрнер В. (1983). Символ и ритуал. Москва: Главная редакция восточной литературы издательства «Наука», 277 с.

Уайнхолд Б., Уайнхолд Дж. (2009). Противозависимость: бегство от близости. Каменец-Подольский: Аксиома, 2009. - 328 с.

Фільц О., Седих К. (2018). Михайлів С. Фіксована уява як механізм виникнення узалежнення. Психологія $i$ особистість. № 2 (14). C. 9-22.

Чиксентмихайи М. (2018). Поток. Психология оптимального переживания. Альпина нон-фикшн. 464 с.

Goswick, R. (1982). Components of Looneliness During Adolescence. Journal of Youth and Adolescence, 11, 373-383.

Greene J. (2014). Moral Tribes: Emotion, Reason, and the Gap Between Us and Them. Penguin Books.

Knutson B. et al. (2000). FMRI Visualization of Brain Activity During a Monetary Incentive Delay Task. Neuroimage 12.

Steinberg L. (2014). Age of Opportunity: Lessons from the New Science of Adolescence. New York: Houghton Miffin.

Оригінальний рукопис отриманий 12 березня 2019 року

Стаття прийнята до друку 15 березня 2019 року 